\title{
Anti-Malarial Activity and Toxicological Effect of Combined Corymbia Citriodora, Maytenus Senegalensis and Warbugia Ugandensis as Used in Traditional Medicine in Kenya
}

\author{
Sarah Atambo ${ }^{1} \quad$ Peter K. Njenga $^{1} \quad$ Festus Tolo $^{2 *}$ \\ 1.Jomo Kenyatta University of Agriculture and Technology, Nairobi CBD Campus \\ 2.Centre for Traditional Medicine and Drug Research, Kenya Medical Research Institute, Nairobi, Kenya
}

\begin{abstract}
Malaria is majorly caused by Plasmodium falciparum resulting in thousands of deaths every year. In Africa, it is a key contributor to the disease burden notable in the disability adjusted life years (DALYs). About 243 million individuals are at a risk of contracting the disease and a higher rate of deaths are observed in children under the age of five. Conventional drugs are available at a subsidized rate but the rising problem is the resistance of the plasmodium parasite to these drugs. Hence, there is an urgent need for the development of new and alternative therapeutics for treatment of malaria. In some regions in Kenya, parts of locally available plants are harvested and used for treating malaria. It is estimated that locally, $30 \%$ of the population relies on traditional medicine for treating various ailments due to the lack of infrastructure and accessible medical facilities especially in the rural areas. Warbugia ugandensis, Maytenus senegalensis and Corymbia citriodora are amongst the plants used in herbal medicine for the treatment of malaria. However, their combinatorial antimalarial efficacy and safety is yet to be determined hence the aim of this study. The plants were harvested from their natural habitats and transported to the Centre of Traditional Medicine and Drug Research (CTMDR) at the Kenya Medical Research Institute (KEMRI), Nairobi. Antimalarial properties of single and combined extracts were analyzed against Plasmodium berghei in vivo. Cytotoxic properties of the plants were carried out against the vero cell-lines in vitro by the MTT assay. Acute oral toxicity was conducted according to the OECD protocol. Effective concentration $\left(\mathrm{ED}_{50}\right)$, cytotoxicity concentration $\left(\mathrm{CC}_{50}\right)$ and median lethal dose (LD50) were derived. The result indicated that the combination of $M$. senegalensis: $W$. ugandensis $(1: 1)$ had the most antimalarial activity at $\mathrm{ED}_{50}$ of $1.05 \mathrm{mg} / \mathrm{kg}$ whereas among the single plants $W$. ugandensis had the highest antimalarial activity (ED ${ }_{50}$ of $3.3 \mathrm{mg} / \mathrm{kg}$ ). The combinations of $C$. citriodora: $M$. senegalensis: W. ugandensis (1:1:1), C. citriodora: $M$. senegalensis: $W$. ugandensis (1:0.5:1) and C. citriodora: $M$. senegalensis: $W$. ugandensis $(0.5: 1: 0.5)$ showed cytotoxicity concentration $\left(\mathrm{CC}_{50}\right)$ of $101.47 \pm 3.17 \mu \mathrm{g} / \mathrm{ml}, 213.55 \pm 3.47 \mu \mathrm{g} / \mathrm{ml}$ and $575.80 \pm 31.40 \mu \mathrm{g} / \mathrm{ml}$ respectively. All the plants combinations showed no cytotoxic effects. The synergistic antimalarial properties of combined C. citriodora: $M$. senegalensis, C. citriodora: W. ugandensis and M. senegalensis: W. ugandensis were confirmed as the extracts showed SFIC indexes of $0.67,0.83$ and 0.28 respectively. All the plant extracts demonstrated $\mathrm{LD}_{50}$ above $2000 \mathrm{mg} / \mathrm{kg}$ with no adverse effects hence recognized as safe. This study confirms the safety and antimalarial activities of these plants and justify their use in herbal medicine practices. The results of this study sets the precedence for the development of an antimalarial herbal formulation that is less toxic and more affordable.
\end{abstract}

Keywords: Anti-Malarial Activity, Toxicological Effect, Traditional Medicine

DOI: $10.7176 / \mathrm{JNSR} / 12-22-04$

Publication date: November $30^{\text {th }} 2021$

\section{Introduction}

Malaria is a mosquito-borne parasitic disease caused by Plasmodium species (Miller et al., 2013; Ghani, 2018). Mammalian hosts are the exclusive targets for Plasmodium falciparum and Plasmodium vivax with the former causing the most malaria burden globally (Global Health, 2008; Tangpukdee et al., 2009; Clemente and Corigliano, 2012). Various strategies have been enlisted for the treatment, management and eradication of the disease such as vector control, chemosuppression and vaccines. Despite all the established efforts to eradicate malaria, the disease still causes significant morbidity and mortality especially in developing countries. Inaccessibility and unaffordability of conventional healthcare for treatment of malaria has motivated communities to use herbal medicine for the management of malaria. Approximately, $75 \%$ of the African population uses traditional medicine for treating human ailments (Clarkson et al., 2004; Ogollah, 2015). It has been suggested that the development of direct herbal formulations will provide dosage descriptions leading to cheaper and more affordable sources of drugs to the communities in which they belong. Due to natural origin and prolonged traditional use of herbal medicines they are considered safe (Willcox and Bodeker, 2004). Primarily, mortality and morbidity rates caused by malaria have reduced because of local herbal therapeutics particularly in parts of developing countries where conventional antimalarial drugs are not readily accessible, affordable and available (Kigondu et al., 2011). Despite their continued use, herbal treatments have a number of 
deficits such as lack of precise diagnosis from laboratory results, plant extracts identification may be obscure, their chemical constituents are unknown and their efficacy yet validated scientifically (Ancolio, et al., 2002). World Health Organization recommends that plant efficacy and safety should be scientifically validated. More importantly based on the scientific background the plants can serve as novel drugs or templates for development of new therapeutic drugs. Hence, the basis of this study.

\subsection{Materials and Methods}

\subsection{Materials}

2.1.1 Plant materials

The Plant materials; Warbugia ugandensis stem bark from Kinangop, Maytenus senegalensis stem bark from Kinangop and Corymbia citriodora leaves from Tharaka Nithi, $5 \mathrm{~kg}$ each were collected in gunny bags from their natural habitat in Kenya. Authentication was done at the East African herbarium, National Museum of Kenya and voucher specimen subsequently deposited at the herbarium. A taxonomist was involved during the collection and authentication process. The plant parts were then delivered to CTMDR, KEMRI.

\begin{tabular}{|llcc|}
\hline Botanical Name & Family & Voucher Number & Parts used \\
Corymbia citriodora & Myrtle & PK03 & Leaves \\
Warbugia Ugandensis & Magnoliidae & TFm11 & Stem bark \\
Maytenus senegalensis & Celestaceae & Fm 10 & Stem bark \\
\hline
\end{tabular}

\subsubsection{Animals}

Swiss mice (18- 25g) were obtained from the animal facility at Kenya Medical Research Institute, Nairobi. The mice were nulliparous and acclimatized to experimental room for a fortnight. The animals were supplied with water ad libitum and food as per experimental procedures. The mice were placed in standard conditions of humidity (40-65\%), temperature and 12-hour light/ darkness cycle.

2.1.3 Innoculum

The chloroquine sensitive Plasmodium berghei (ANKA) was obtained from Kenya Medical Research Institute Nairobi. A Swiss mouse containing $P$. berghei at a parasitaemia level of $20-30 \%$ was used as the donor inoculum. Parasitized erythrocytes were harvested from the donor mouse using a sterile needle and syringe coated with heparin. The blood was then diluted with phosphate saline glucose(PSG) buffer to obtain $1 \mathrm{ml}$ blood containing $1 \times 10^{7}$ parasitized erythrocytes.

\subsection{Methods}

\subsubsection{Plant material}

Clean plant parts were air- dried at room temperature $\left(25^{\circ} \mathrm{C}\right)$ for a fortnight. Once completely dried, the plant parts were ground using an electric mill into powder form then separately stored in sealed containers at room temperature. A portion $(100 \mathrm{~g})$ of each of the powdered plant part was put in 1 litre of distilled water and heated in a water bath at $70^{\circ} \mathrm{C}$ for 90 minutes. The extract was decanted into a clean dry 3 litre conical flask followed by filtering through a cotton gauze. The filtered extract was then lyophilized using an Edwards freeze dryer Modulyo into powder form and then pooled into an air tight bottle, weighed, labeled and stored at $4^{0} \mathrm{C}$ awaiting use.

\subsubsection{Cell cultures}

Vero E6 cell line cells obtained from the American Type Culture Collection were cultured in Minimum Essential Media supplemented with L-Glutamine, $10 \%$ heat inactivated fetal bovine serum (FBS), $1 \%$ of penicillin and streptomycin then maintained at $37^{\circ} \mathrm{C}$ in a humidified atmosphere of $5 \% \mathrm{CO}_{2}$.

2.2.2.1 MTT assay

An amount of $50 \mathrm{mg}$ each of the different extract ratios was dissolved in $5 \mathrm{ml}$ double distilled water to give stock solutions of $10 \mathrm{mg} / \mathrm{ml}$ each. This stock solution was then dissolved in $0.5 \mathrm{ml}$ DMSO Dimethyl Sulfoxide (DMSO). Double distilled water was then added to give a stock solution of $10 \mathrm{mg} / \mathrm{ml}$ ensuring that the final concentration of DMSO is $1 \%$ as it is toxic beyond this percentage. This one-part stock solution was diluted to 99 parts of Earl's Minimum Essential Medium (MEM) (ratio of 1:99), containing 2\% Fetal Bovine Serum (FBS, maintenance medium), which was $10 \mu 1$ of the extract in $990 \mu 1$ of media giving a start concentration of $1000 \mu \mathrm{g} /$ $\mathrm{ml}$ in 1\% DMSO used in the MTT ((3- [4, 5- dimethylthiazol -2- yl) -2,5- diphenyltetrazolium bromide) assay.

In vitro cytotoxicity assay was carried out following a modified rapid calorimetric assay Mosmann (1983). Vero E6 cell line, 1ml, containing 1500-2000 cells was retrieved from liquid nitrogen storage and viability of the cells determined using Trypan blue exclusion assay. The cells were revived and cultured in T-75 flasks with Earl's Minimum Essential Media (EMEM), supplemented with penicillin \& streptomycin (1\%) and 10\% Fetal Bovine Serum maintained at $37^{\circ} \mathrm{C}$ in a humidified atmosphere of $5 \% \mathrm{CO}_{2}$ to achieve a monolayer.

Cell monolayer was broken into single cells using trypsin after achieving 70-100\% confluence. Cell density count of viable cells was determined. A 96- well micro titer plate was used. A cell suspension (10 $\mu 1)$ containing $2 \times 10^{5}$ viable cells was then seeded onto columns $1,2,4,5,7,8,10,11$ whereas $10 \mu 1$ of media without vero cells 
was added onto rows 3,6,9 and 12 . The plate was then incubated at $37^{\circ} \mathrm{C}$ in $5 \% \mathrm{CO}_{2}$ for 24 hours to allow the cells to attach. After which the different combination of the drugs was serially added to the cells from rows $\mathrm{H}$ to row B.

Treatment protocol for cytotoxicity assay

\begin{tabular}{lc}
\hline Treatment Groups & Concentration $(\mu \mathrm{l} / \mathrm{ml})$ \\
\hline Negative Control (Distilled water) & 150 \\
Positive Control & 15 \\
Extract Treatments & 1.37 \\
i. & 4.12 \\
ii. & 12.35 \\
iii. & 37.04 \\
iv. & 111.11 \\
v. & 333.33 \\
vi. & 1000 \\
vii. & \\
\hline
\end{tabular}

Different combination ratios of the combined drug extracts of C.citriodora, M.senegalensis and W.ugandensis was serially added to the wells. The plates were then incubated for 48 hours at $37^{\circ} \mathrm{C}$ in $5 \% \mathrm{CO}_{2}$. Upon incubation, $10 \mu \mathrm{L}$ of MTT dye was added to all the cells in the plates. The plates were incubated for another 4 hours then entire media plus MTT dye was aspirated off followed by addition of $100 \mu 1$ of DMSO and shaken for 5 minutes to dissolve the formazin.

The plates were read on a scanning multi well spectrophotometer (Multiskan Ex Labssystems) at $562 \mathrm{~nm}$ and $690 \mathrm{~nm}$ as reference to determine the extent of cell viability.

2.2.1 Four day chemosuppressive antimalarial activity test

The blood was obtained from the second passage and collected in containers coated with heparin. The blood was diluted with phosphate saline glucose buffer(PSG) to obtain $1 \mathrm{ml}$ blood containing $1 \times 10^{7}$ parasitized erythrocytes. A volume of $0.2 \mathrm{ml}$ per mouse containing $1 \times 10^{7}$ parasitized erythrocytes was intraperitoneally injected into 25 mice using a 27-gauge needle. The animals were then randomly divided into six groups each comprising of five animals. After 2 hours, a randomized group of animals was orally treated with the vehicle; distilled water), reference drug (Chloroquine) and plant extracts as shown in table 3.2 using a 26-gauge stainless steel cannula. The group treated with the vehicle served as the negative control while chloroquine treated group was the positive control. On the $4^{\text {th }}$ day, the mice were pricked at the tail tip and drops of blood collected on a microscope slide. The collected blood was used to prepare thin smears which were stained with giemsa dye then viewed under a microscope to observe and count the number of infected red blood cells. Parasitemia was determined microscopically by counting four fields on the microscope slide having approximately 100 erythrocytes per field. The number of infected erythrocytes against the number of total erythrocytes in the field was recorded.

$\%$ Parasitemia $=$ Number of Parasitized RBCs $\times 100$

Total number of RBCs

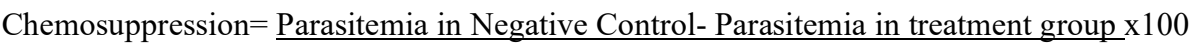

Parasitemia in Negative Control

2.2.4 In vivo acute toxicity

The acute oral toxicity test was closely monitored in intervals of $0,15,30,45 \mathrm{~min}, 1 \mathrm{hour}, 6 \mathrm{hr}, 12 \mathrm{hr}, 24 \mathrm{hr}, 36 \mathrm{hr}$, $48 \mathrm{hr}$ according to OECD 425 protocol (OECD, 2005). Fifteen nulliparous and non-pregnant female (8-12 weeks old, 18 - 25g) Swiss mice were acclimatized to laboratory conditions for five days prior to dosing. Five groups (comprised of three mice) were randomly picked and placed in a marked cage. The mice were fasted for 3 hours prior dosing and their weight determined. A single dose of $0.2 \mathrm{ml}(1 \mathrm{ml} / 100 \mathrm{~g}$ of mouse weight) containing combined plant extract at $5,50,300,2000 \mathrm{mg} / \mathrm{kg}$ body weight doses was orally administered per group of mice using a 20 gauge oral gavage stainless steel cannula. Food was withheld for 2 hours after treatment with the plant extract.

A single group of mice ( 3 mice) were first administered with $5 \mathrm{mg} / \mathrm{kg}$ initial dose and monitored for 48 hours. If none or one mouse dies, then a higher dose would be administered to another group of three mice. The first 48 hours for observation is crucial to ensure survival of the group of mice before proceeding to a higher dose. Toxicity was monitored and the vehicle/ negative control (distilled water) was given to the normal group. Signs of toxicity such as changes in breathing patterns, weight loss, reduced activeness and eventual death were checked within the first 48 hours after treatment. At the end of 14 days, weight of the surviving animals was recorded and humanely sacrificed. 
3.0 RESULTS AND DISCUSSION

3.1 Plant extract species and yield

\begin{tabular}{|llll|}
\hline Plant species & Part & Weight before yield (g) & Weight after yield \\
\hline Corymbia citriodora & Leaf & 100 & 11.2 \\
Maytenus senegalensis & Stem bark & 93 & 17.5 \\
Warbugia ugandensis & Roots & 100 & 23.91 \\
\hline
\end{tabular}

The percentage yield of the plant extract Corymbia citriodora was slightly higher than the ethanolic E. citriodora extract of $9.32 \%$ by Muhammed et al (D.Muhammed, 2018).

3.2 In vitro cytotoxicity of $C$. citriodora, $M$. senegalensis and W. ugandensis

In vitro safety profile of the plant extract was established by determined the concentration that reduced vero cells by $50 \%$ (CC50). Chloroquine had the highest cytotoxic effect with a $\mathrm{CC}_{50}$ value of $71.13 \pm 1.63 \mu \mathrm{g} / \mathrm{ml}$. $C$. citriodora: $M$. senegalensis: $W$. ugandensis $(1: 1: 1)$ and $C$. citriodora: $M$. senegalensis: $W$. ugandensis $(1: 0.5: 1)$ had $\mathrm{CC}_{50}$ value of $101.47 \pm 3.17 \mu \mathrm{g} / \mathrm{ml}$ and $213.55 \pm 3.47 \mu \mathrm{g} / \mathrm{ml}$ respectively with no observed cytotoxicity to the vero cells. The least $\mathrm{CC}_{50}$ was shown by $C$. citriodora: M. senegalensis: $W$. ugandensis $(0.5: 1: 0.5)$ at of $575.80 \pm 31.40 \mu \mathrm{g} / \mathrm{ml}$. The cytotoxicity exhibited by chloroquine was statistically higher from the cytotoxicity shown by all the plant extracts.

Table 3.2.1 Cytotoxic effects of various extract combination on vero cells

\begin{tabular}{lc} 
Treatments & CC $_{\mathbf{5 0}}$ Values $(\boldsymbol{\mu g} / \mathbf{m l})$ \\
\hline Chloroquine & $71.13 \pm 1.63$ \\
C. citriodora: M. senegalensis: W. ugandensis $(1: 1: 1)$ & $101.47 \pm 3.17$ \\
C. citriodora: M. senegalensis: $W$. ugandensis $(1: 0.5: 1)$ & $213.55 \pm 3.47$ \\
C. citriodora: M. senegalensis: $W$. ugandensis $(0.5: 1: 0.5)$ & $575.80 \pm 31.40$ \\
\hline All
\end{tabular}

All values are expressed as Mean \pm SEM

The MTT ([3-(4, 5-dimethylthiazol-2-yl) 2, 5-diphenyl tetrazolium bromide]) assay is used to test for cell viability in which living cells reduce tetrazolium salt in a reaction catalyzed by the mitochondrial dehydrogenase enzyme (Freimoser et al., 1999; Ogollah, 2015). Vero cells are recommended for cytotoxicity assays of plant extracts and nutraceuticals in biomaterial research since they mimic normal body cells (Kirkpatrick, 1992; ISO, 1997). The cell line was subjected to extracts treatment upon which the $\mathrm{CC}_{50}$ values were determined. Accordingly, C. citriodora: M. senegalensis: W. ugandensis (1:1:1), C. citriodora: M. senegalensis: $W$. ugandensis (1:0.5:1) C. citriodora: M. senegalensis: W. ugandensis $(0.5: 1: 0.5)$ showed no cytotoxic effects with $\mathrm{CC}_{50}$ values of $101.47 \pm 3.17 \mu \mathrm{g} / \mathrm{ml}, 213.55 \pm 3.47 \mu \mathrm{g} / \mathrm{ml}$ and $575.80 \pm 31.40 \mu \mathrm{g} / \mathrm{ml}$ respectively.

Previous findings corroborate the safety properties of the aqueous extract of the plant extracts as observed in the current study. Nabende (2015) corroborated the findings of this study where it was observed that the aqueous leaf extracts of $M$. senegalensis had no cytotoxic effects against the vero cell lines (CC50 values $>1000 \mu \mathrm{g} / \mathrm{ml}$ ). This study also confirms the findings of Nobakht et al. (2017) that C. citriodora, C. torelliana $C$. citriodora and C. torelliana showed no cytotoxicity activity Vero cells tested using $1000 \mu \mathrm{g} / \mathrm{ml}$.

\subsection{Four day chemosuppressive antimalarial activity test}

Combinations of two plants extracts were tested for antimalarial activity. The combinations tested included $C$. citriodora: $M$. senegalensis $(\mathrm{C}: \mathrm{M})$, C. citriodora: $W$. ugandensis $(\mathrm{C}: \mathrm{W})$ and $M$. senegalensis: W. ugandensis $(\mathrm{M}: \mathrm{W})$ at the ratio of 1:1. The percentage chemosuppression of $P$. berghei growth by all the extracts was statistically lower than the positive control chloroquine but statistically higher than the negative control.

It was observed that the combinations of $C$. citriodora: $M$. senegalensis $(\mathrm{C}: \mathrm{M})$ and $M$. senegalensis: $W$. ugandensis (M: W) had dose related antimalarial activity. Correspondingly, as the concentration of the extracts increased, the percentage chemosuppression of $P$. berghei proliferation reduced (table 3.3.1). On the other hand, C. citriodora: W. ugandensis $(\mathrm{C}: \mathrm{W})$ showed highest chemosuppression $(88.80 \pm 0.44 \%)$ at lowest concentration of $75 \mathrm{mg} / \mathrm{kg}$ (table 3.3.1). Comparison of the three extracts indicated that M. senegalensis: W. ugandensis (M: W) had the highest chemosuppression activity of $95.35 \%$ in comparison to Chloroquine. The combination of $C$. citriodora: $M$. senegalensis $(\mathrm{C}: \mathrm{M})$ had the lowest chemosuppression activity of $76.72 \%$ in comparison to all the other extracts used in this study. 


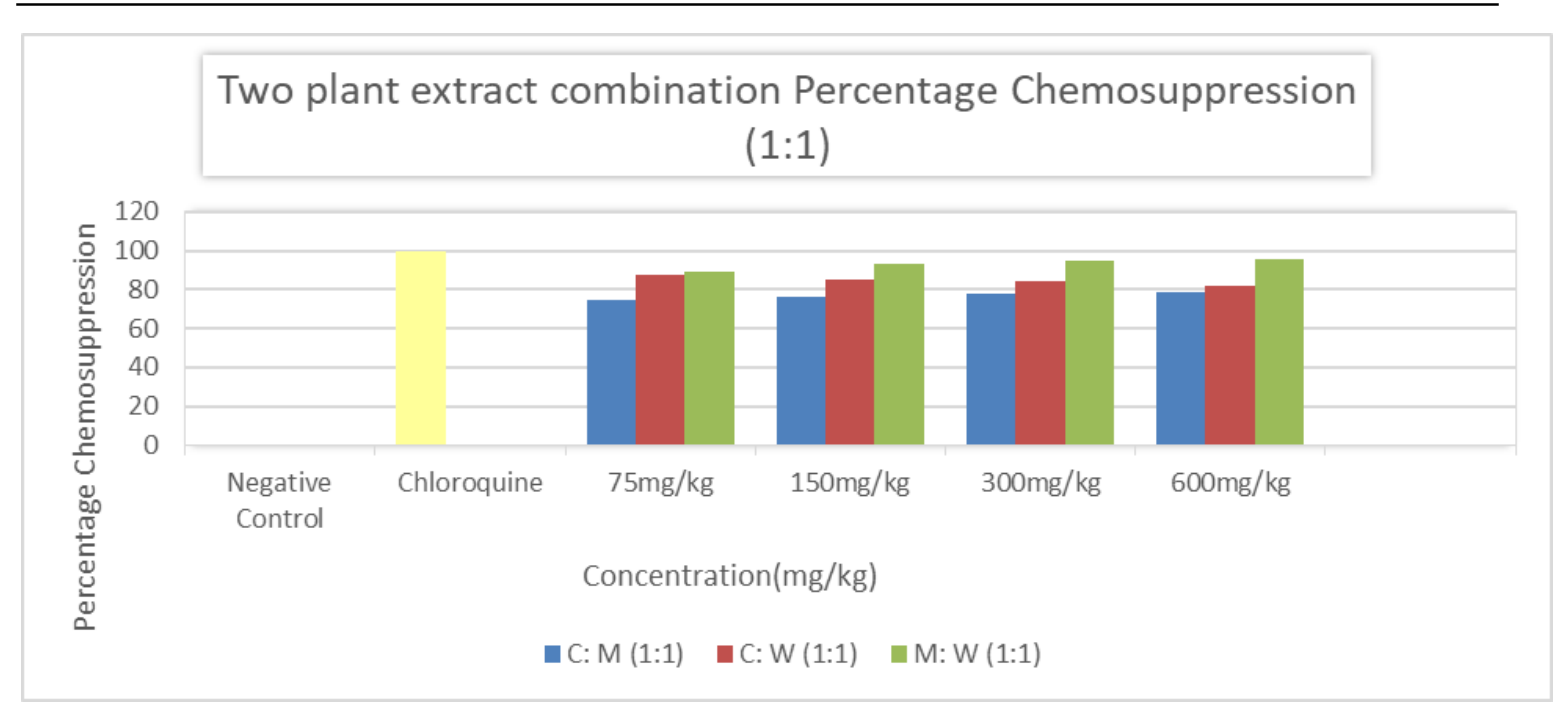

Further, the three plants (C. citriodora: W. ugandensis: M. senegalensis) were combined in the ratio of 1:1:1 and their antimalarial activities determined (table 3.3.2). An inverse dose dependent trend of inhibition was observed. Consequently, the highest percentage chemosuppression $(77.06 \pm 0.41 \%)$ was observed at the lowest concentration $(75 \mathrm{mg} / \mathrm{kg})$ of the plant extracts. The results also indicated that the combination of the three plants was statistically higher than the negative control group although statistically lower than the standard drug chloroquine. The three plant combination extract showed lower chemosuppression values than the two plant extract combinations. This highlights the need to sensitize the community on the importance of extract combination ratios when using plants for treating ailments to improve efficacy as well as safety (Rasoanaivo et al., 2011)

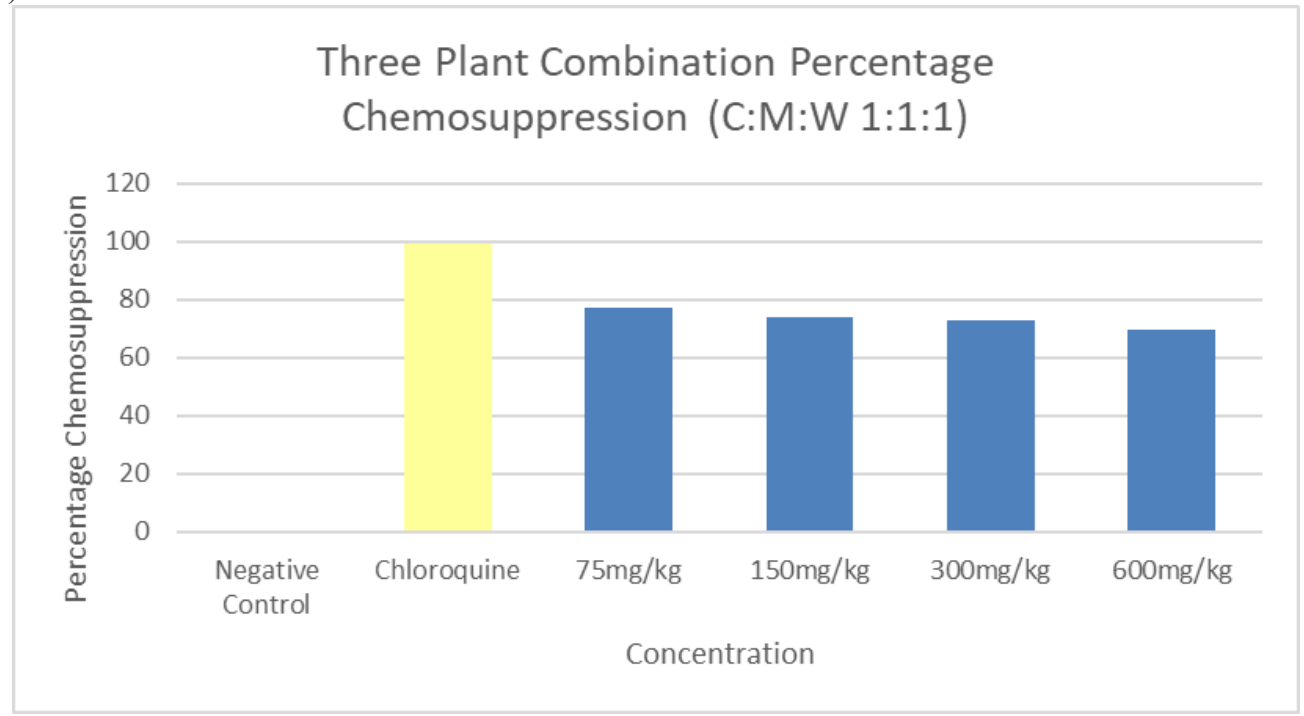

\subsection{Acute Toxicity}

Acute toxicity of the plant extracts was carried out on Swiss mice and body weights determined. Generally, there was an increment of the animals' body weight after the extract administration hence extract administration did not affect weight gain. Mortality did not occur from onset of drug administration until the 14- day observation period. No animals died at the highest concentration of the treatment hence the lethal dose $\left(\mathrm{LD}_{50}\right)$ was inferred to be above $2000 \mathrm{mg} / \mathrm{kg} /$ oral hence considered safe and nontoxic (Bello et al., 2005). The mice behavioral indicators such as reduced activity, diarrhea, paw licking, convolution and hyperactivity were not observed in this study. 
Table 3.5.1 Effects of $C$. citriodora: $M$. senegalensis: $W$. ugandensis $(1: 1: 1)$ on mice body weight

\begin{tabular}{|c|c|c|c|}
\hline Concentrations & $\begin{array}{l}\text { Weight before extract } \\
\text { administration }(\mathrm{g})\end{array}$ & $\begin{array}{l}\text { Weight after extract } \\
\text { administration (g) }\end{array}$ & $\begin{array}{l}\text { Percentage } \\
\text { change (g) }\end{array}$ \\
\hline Distilled water & $19.80 \pm 0.37^{\mathrm{a}}$ & $27.00 \pm 0.71^{\mathrm{a}}$ & $27.67 \pm 3.17^{\mathrm{a}}$ \\
\hline $5 \mathrm{mg} / \mathrm{kg}$ & $20.20 \pm 0.66^{\mathrm{a}}$ & $27.60 \pm 0.51^{\mathrm{a}}$ & $24.60 \pm 1.08^{\mathrm{a}}$ \\
\hline $50 \mathrm{mg} / \mathrm{kg}$ & $20.20 \pm 0.66^{\mathrm{a}}$ & $27.00 \pm 0.45^{\mathrm{a}}$ & $25.13 \pm 2.64^{\mathrm{a}}$ \\
\hline $300 \mathrm{mg} / \mathrm{kg}$ & $19.60 \pm 0.51^{\mathrm{a}}$ & $26.40 \pm 0.81^{\mathrm{a}}$ & $24.98 \pm 3.35^{\mathrm{a}}$ \\
\hline $2000 \mathrm{mg} / \mathrm{kg}$ & $19.40 \pm 0.51^{\mathrm{a}}$ & $26.00 \pm 0.32^{\mathrm{a}}$ & $24.54 \pm 2.46^{\mathrm{a}}$ \\
\hline Chloroquine & $19.00 \pm 0.32^{\mathrm{a}}$ & $26.00 \pm 1.00^{\mathrm{a}}$ & $26.50 \pm 2.05^{\mathrm{a}}$ \\
\hline $\mathrm{LD}_{50}$ & \multicolumn{2}{|c|}{$>2000 \mathrm{mg} / \mathrm{kg}$} & \\
\hline
\end{tabular}

All values are expressed as Mean \pm SEM,

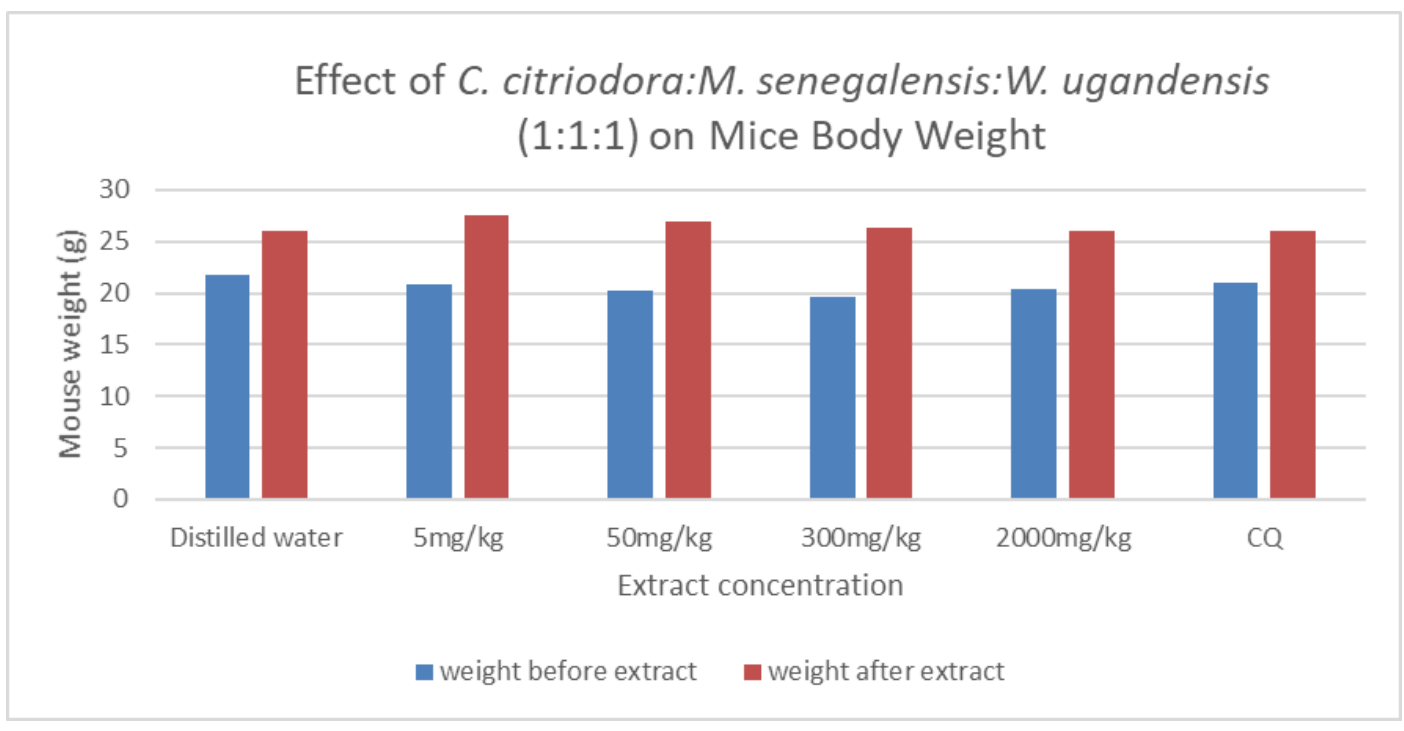

\subsection{CONCLUSION}

The significant findings from this study supports the antimalarial ethnomedicinal claimed combination of C.citriodora, M.senegalensis and W.ugandensis in treating malaria. Attention to the extract combination ratios is crucial for the effective treatment of malaria. The results show a possibility of developing new anti-malarial novel compound using thorough molecular mechanism and characterization studies.

\section{Acknowledgements}

I am grateful to my supervisors Dr. Festus Tolo, from the Centre of Traditional Medicine and Drug Research (CTMDR, KEMRI) and Prof. Peter Njenga (Jomo Kenyatta University of Agriculture and Technology), for enabling the successful undertaking of this study.

\section{ETHICAL APPROVAL}

Ethical Approval was obtained from Kenya Medical Research Institute (KEMRI) Scientific Steering Committee (SSC). Ethical Review Committee (ERC) and Animal care and Use Committee (ACUC) before commencement of the study.

\section{REFERENCES}

Ancolio, C., Azas, N., Mahiou, V., Ollivier, E., Di Giorgio, C., Keita, A., \& Balansard, G. (2002). Antimalarial activity of extracts and alkaloids isolated from six plants used in traditional medicine in Mali and Sao Tome. Phytotherapy Research: An International Journal Devoted to Pharmacological and Toxicological Evaluation of Natural Product Derivatives, 16(7), 646-649.

Bello SO, Muhammad BY, Gammaniel KS, Abdu -Aguye I, Ahmed H, Njoku CH, Pindiga UH Salka AM. Preliminary evaluation of the toxicity and some pharmacological properties of the aqueous crude extract of Solanum Melongena. Research Journal of Agriculture and Biological Science. 2005;1(1):1-9.

Clarkson, C., Maharaj, V. J., Crouch, N. R., Grace, O. M., Pillay, P., Matsabisa, M. G., ... \& Folb, P. I. (2004). In vitro antimalarial activity of medicinal plants native to or naturalised in South Africa. Journal of ethnopharmacology, 92(2-3), 177-191. 
Clemente, M., \& Corigliano, M. G. (2012). Overview of plant-made vaccine antigens against malaria. BioMed Research International, 2012, 1-8

Freimoser, F. M., Jakob, C. A., Aebi, M., \& Tuor, U. (1999). The MTT [3-(4, 5-dimethylthiazol-2-yl)-2, 5diphenyltetrazolium bromide] assay is a fast and reliable method for colorimetric determination of fungal cell densities. Appl. Environ. Microbiol., 65(8), 3727-3729.

Ghani, Azra C. "Can improving access to care help to eliminate malaria?." The Lancet 391, no. 10133 (2018): $1870-1871$.

Global Health, (2008). Division of Parasitic Diseases and Malaria.

International Organization for Standardization (ISO), (1997). Biological evaluation of medical devices: Part 5. Tests for cytotoxicity: in vitro methods. $1^{\text {st }}$ ed. ISO. Geneva. 1-7.

Kigondu, E.V.M., Rukunga, G.M., Gathirwa, J.W., Irungu, B.N., Mwikwabe, N.M., Amalemba, G.M., Omar, S.A. and Kirira, P.G. (2011). Antiplasmodial and cytotoxicity activities of some selected plants used by the Maasai community, Kenya. South African Journal of Botany, [online] 77(3), pp.725-729.

Kirkpatrick, C. J. (1992). Biological testing of materials and medical devices-A critical view of current and proposed methodologies for biocompatibility testing: cytotoxicity in vitro. Regulatory Affairs, 4(1), 13-32.

Miller, L. H., Ackerman, H. C., Su, X. Z., \& Wellems, T. E. (2013). Malaria biology and disease pathogenesis: insights for new treatments. Nature medicine, 19(2), 156.

Muhammed, D., Dada, E. O., Muazu, M., Jumbo, E. I., \& Uzokwe, V. I. (2018). Antimalarial Activity of Ethanolic Leaf Extract of Eucalyptus citriodora in Swiss Mice Infected with Plasmodium berghei NK 65. South Asian Journal of Research in Microbiology, 1-10.

Nabende, P. N. (2015). Safety and anti-proliferative activity of Prunus africana, Warburgia stuhlmannii and Maytenus senegalensis extracts in breast and colon cancer cell lines (Doctoral dissertation).

Nobakht, M., Trueman, S., Wallace, H., Brooks, P., Streeter, K., \& Katouli, M. (2017). Antibacterial properties of flavonoids from kino of the eucalypt tree, Corymbia torelliana. Plants, 6(3), 1-16.

OECD, (2005). OECD Guideline for testing of chemicals. The Organisation for Economic Co-operation and Development: Paris, France, 1-13.

Ogollah, J. O. (2015). In Vivo Antimalarial Activity, Toxicity and Phytochemical Composition of Securidaca Longepedunculata Fresen.(Polygalaceae) (Doctoral dissertation, University of Nairobi).

Rasoanaivo, P., Wright, C.W., Willcox, M.L. and Gilbert, B. (2011). Whole plant extracts versus single compounds for the treatment of malaria: synergy and positive interactions. Malaria Journal, 10(S1).

Willcox, M. L., \& Bodeker, G. (2004). Traditional herbal medicines for malaria. Bmj, 329(7475), 1156-1159. 